\title{
Where is the protein? An analysis of fast food in Mexico and its implications for Public Health
} ¿Dónde está la proteína? Un análisis de la comida rápida
en México y sus implicaciones para la Salud Pública

\author{
Teresa Díaz-Flores ${ }^{1 *}$, VAn C. LANSingh ${ }^{2}$, Catherine A. McCarty ${ }^{3}$, Ellery M. LóPez-STAR ${ }^{4}$, \\ SONIA CORREDOR-CASAS ${ }^{5}$ AND SERGE RESNIKOFF ${ }^{6}$
}

\begin{abstract}
${ }^{1}$ Anterior Segment Department; ${ }^{2}$ General Director; Instituto Mexicano de Oftalmología IAP, Santiago de Querétaro, Querétaro, México; ${ }^{3}$ Investigation department, Essentia Institute of Rural Health, University of Minnesota Medical School, Duluth Campus, Duluth, Minnesota, USA; ${ }^{4}$ Medical Management; ${ }^{5}$ Ophthalmic Pathology, Instituto Mexicano de Oftalmología IAP, Santiago de Querétaro, Querétaro, México; ${ }^{6}$ Investigation department, Brien Holden Vision Institute and SOVS, University of New South Wales, Sydney, Australia
\end{abstract}

\section{ABSTRACT}

To assess nutritional content particulary of protein of chicken nuggets and beef hamburgers of major international fast-food chains in Queretaro, Mexico. We purchased three orders of nuggets and three orders of hamburgers from five different fast-food restaurants. We randomly selected one nugget and a piece of hamburger meat from each order, resulting in a total of 27 specimens. The fast-food specimens were compared to a sample control piece made at home. The histopathology analysis was blinded. Samples were stained with hematoxylin, eosin, and Masson's trichrome and evaluated by light microscopy. The hamburgers' content of cartilaginous tissue ranged between $0 \%$ and $25 \%$, while other components ranged between $20 \%$ and $75 \%$. Skeletal muscle tissue showed variability of $15-75 \%$. The percentage of skeletal muscle tissue among nuggets ranged from $5 \%$ to $70 \%$, while their other components ranged between $20 \%$ and $80 \%$. Nuggets and hamburgers sold at fast-food chains

\section{RESUMEN}

Se evaluó el contenido nutricional de los nuggets de pollo y hamburguesas de las principales cadenas internacionales de comida rápida en Querétaro, México. Compramos 3 órdenes de nuggets y 3 de hamburguesas de 5 diferentes restaurantes de comida rápida. Se seleccionó al azar 1 nugget y un pieza de carne de la hamburguesa de cada orden, resultando en un total de 27 muestras. Se comparó con una muestra control casera. El análisis de la histopatología fue ciego. Las muestras fueron teñidas con hematoxilina y eosina y tricómica de Masson y se evaluaron por microscopía óptica. El contenido de tejido cartilaginoso en las hamburguesas varió de 0 a $25 \%$, mientras que otros componentes oscilaron entre 20-75\%. El tejido muscular esquelético mostró una variabilidad (15 a 75\%). Los nuggets analizados tuvieron un porcentaje de músculo esquelético de 5 a $70 \%$, mientras que otros componentes oscilaron entre el 20 y $80 \%$. Los nuggets y hamburguesas que se venden en las cadenas de comida
Correspondencia:

*Teresa Díaz-Flores

E-mail: diazfteresa@gmail.com
Fecha de recepción: 15-04-2019

Fecha de aceptación: 25-10-2019

DOI: 10.24875/RME.19001928
Disponible en internet: 28-11-2019 Rev Mex Endocrinol Metab Nutr. 2019;6:170-7

2462-4144/@ 2019 Sociedad Mexicana de Nutricion y Endocrinologia, AC. Publicado por Permanyer México. Este es un artículo Open Access bajo la licencia CC BY-NC-ND (http://creativecommons.org/licenses/by-nc-nd/4.0/). 
are a low-protein source and have a high content of fat, which can lead to obesity, diabetes, and their related systemic complications.

Key words: Fast food. Public health. Children. Diabetes. Obesity. Nutrients.

\section{INTRODUCTION}

Chicken nuggets are widely available in national fast-food chains and convenience stores in Mexico. These nuggets are not a good nutritional option due to their low-protein content and high proportion of fats, especially for consumers in a country facing an epidemic of obesity and obesity-related diseases ${ }^{1}$. Similarly, hamburgers sold at fast-food chains represent a food source with a low-protein content $^{2}$. However, there have been no studies in Mexico to provide a histological analysis of the content of the chicken nuggets and hamburger patties sold in our country. This study aims to analyze food samples from five commercial food chains in the municipality of Queretaro, providing nutritional data that can serve as a basis for future strategies to reduce the prevalence of unhealthy weights, obesity, and chronic degenerative diseases.

Epidemiological studies have shown significant changes in eating patterns in Mexico and around the world, and these changes have contributed to an increase in chronic degenerative diseases such as diabetes mellitus and hypertension ${ }^{3,4}$. International health experts have offered dietary recommendations to help prevent unhealthy and obesity and reduce the current burden of these conditions. In 2008, the World Health Organization's Committee of Experts proposed an acceptable range of dietary fat consumption of $15-35 \%$ of daily calories for the general population and of $20-35 \%$ for women of reproductive age. The amount of energy measured in kilocalories, which should be consumed every day varies according to several factors including age, sex, weight, height, and level of physical activity ${ }^{3,4}$.

On the international level, it has been observed that within less than the span of a generation, the prevalence of overweight and obese children has rápida son una fuente baja en proteínas y tienen un alto contenido de grasa, que puede conducir a obesidad, diabetes y sus principales complicaciones sistémica relacionadas.

Palabras clave: Comida rápida. Salud pública. Niños. Diabetes. Obesidad. Nutrientes.

increased in most high-income countries, with $47 \%$ of children in the world having an elevated body mass index $(\mathrm{BMI})^{5}$.

Numerous studies have undertaken the task of analyzing the foods sold in fast-food chains and the effects of consuming them. A study by Duerksen et al. analyzed 223 pairs of children and parents, finding that children from families who ate fast food more often had an increased risk of being overweight (BMI $\geq 85^{\text {th }}$ percentile) (odds ratio: 2.2; confidence interval 95\%: 1.2-4.3), indicating that eating at fast-food restaurants could contribute to being overweight in Mexican-American families living in the United States ${ }^{6}$.

A study carried out by deShazo et al., in 2014, analyzed a sample of chicken nuggets from two restaurant chains, finding that the largest component of the nuggets was fat (sample from restaurant 1: $56 \%$ fat; sample from restaurant 2: $58 \%$ fat), compared to a lower protein content (sample from restaurant 1: $19 \%$ protein; restaurant 2: $18 \%$ protein) ${ }^{1}$. Furthermore, in 2008, Prayson et al. conducted a histopathological analysis of eight brands of commercial fast foods, finding that approximately half of the weight of the burgers was water and only a small percentage was meat $(12.1 \%)^{2}$. Another study examining the meat content of hot dog sausages from eight different commercial brands found that most of the samples consisted 50 of water with the actual amount of meat representing $<10 \%$ of the product weight ${ }^{7}$.

\section{METHODS}

A descriptive study was conducted from June 2015 to August 2015. Orders of chicken nuggets and beef burgers from the selected establishments were analyzed. We purchased three orders of nuggets and 
three burgers from each establishment during three different days to assess the consistency of results. A nugget sample was chosen by simple random selection. We included samples of chicken nuggets and burgers from various food sites in selected neighborhoods within 1 mile of ratio and excluded samples that were not properly preserved or not properly masked for blind analysis by the pathologist. In the case of the nuggets, sampling was performed by simple randomization, choosing a nugget from each order for analysis. In the case of the burgers, a piece was purchased from each establishment on three different days, as suggested by deShazo et al. ${ }^{1}$

We also included a sample of a homemade nugget prepared with ground chicken meat and a sample of a hamburger patty made at home with ground beef to serve as controls, with each control containing an ideal protein content (close to $80 \%$ ) for these food items. For the nuggets, we mixed ground chicken meat, cumin, oregano, and salt, and we then covered it with a layer of beaten egg and breadcrumbs. The nuggets were then fried in hot oil until brown. For the hamburger patties, mixed herbs and spices were combined with ground meat, a patty was formed, and it was fried in oil. Each nugget and hamburger sample was placed in a separate box without commercial logos or trademarks and was assigned a number, one for each commercial chain. The commercial nuggets and hamburger meat samples were analyzed at the same time as the control samples. The pathological analysis was blinded.

Each nugget was sampled by taking a cut of $0.5 \times$ $0.5 \mathrm{~cm}$ meat with a thickness of $0.5 \mathrm{~cm}$ from the central portion and another of equal size from the peripheral area. Each hamburger was sampled by taking a cut measuring $1 \times 1 \mathrm{~cm}$ with a thickness of $0.5 \mathrm{~cm}$ in the center of the piece, along with an additional cut of equal size from the peripheral portion. All of the cuts were fixed in 10\% formaldehyde, processed histologically, and embedded in paraffin. Histological cuts were carried out in the microtome, and then, the samples were dyed with hematoxylin, eosin, and Masson's trichrome stain for assessment through light microscopy. The equipment used to analyze the samples was a Zeiss
Axio A1 scope with a built-in camera (AxioCam ICC5). The $\times 1$ and $\times 5$ objectives were used to evaluate the samples.

The findings were analyzed as a range between the lower and higher percentage values of each tissue type in the totality of photomicrographs of each specimen, and as an average of all the percentages, and descriptive statistics found in the analysis of images for each sample.

\section{RESULTS}

We analyzed 12 samples of hamburgers and 3 samples of hamburger meat from each chain, corresponding to four commercial fast-food chains. One commercial brand of hamburgers was eliminated from the study because its burgers are made from chicken meat. The rest of hamburgers and nuggets were thrown away.

Among the analyzed hamburgers, the prevalence of bone and cartilaginous tissue was found to lie in a range from $0 \%$ to $25 \%$ (mean $0.83-13.33$ with a standard deviation [SD] from 3.76 to 9.70). The presence of skeletal muscle tissue (protein) showed great variability. Some sample values were as low as $15 \%$, while others ranged up to $75 \%$, with the latter corresponding to the homemade sample (mean from 19.17 to 65 , with an SD from 3.76 to 775 ). The homemade sample had a range from $60 \%$ to $75 \%$ (mean 65 , with an SD of 5.48). The sample corresponding to chain No. 2 had a range from 15\% to $25 \%$ (mean 19.17 , with an SD of 3.76). The sample corresponding to chain No. 3 had a range from $30 \%$ to $35 \%$ (mean 39.17, with an SD of 6.65). The sample corresponding to chain No. 4 had a range from $35 \%$ to $55 \%$ (mean 45.00 , with an SD of 7.75 ).

The presence of adipose tissue in hamburger samples ranged from $15 \%$ to $65 \%$ (mean from 18.33 to 48.33 , with an SD form 4.08 up to 13.66). The homemade sample had a range from $15 \%$ to $25 \%$ (mean 18.33 , with an SD of 4.08). The sample corresponding to chain No. 2 had a range from $30 \%$ to $65 \%$ (mean 48.33, with an SD of 13.66). The sample corresponding to chain No. 3 had a range from $30 \%$ to 
Table 1. Range of percentages of muscle tissue content in beef burger samples from different commercial chains

\begin{tabular}{lcccc}
\hline $\begin{array}{l}\text { Food sample } \\
\text { (n of samples) }\end{array}$ & $\begin{array}{l}\text { Range of \% of } \\
\text { muscle tissue }\end{array}$ & Mean & Variance & Standard deviation \\
\hline Homemade $(n=3)$ & $60-75$ & 65.00 & 30.00 & 5.48 \\
\hline $2(n=3)$ & $15-25$ & 19.17 & 14.17 & 3.76 \\
\hline $3(n=3)$ & $20-35$ & 30.00 & 30.00 & 5.48 \\
\hline $4(n=3)$ & $15-40$ & 45.00 & 60.00 & 7.75 \\
\hline Information derived from the study data & & & &
\end{tabular}

Table 2. Range of percentages of adipose tissue content in beef burger samples from different commercial chains

\begin{tabular}{lcccc}
\hline $\begin{array}{l}\text { Food sample } \\
\text { (n of samples) }\end{array}$ & $\begin{array}{l}\text { Range of \% of } \\
\text { adipose tissue }\end{array}$ & Mean & Variance & Standard deviation \\
\hline Homemade $(n=3)$ & $15-25$ & 18.33 & 16.67 & 4.08 \\
\hline $2(n=3)$ & $30-65$ & 48.33 & 186.67 & 13.66 \\
\hline $3(n=3)$ & $30-45(n=3)$ & 39.17 & 44.17 & 6.65 \\
\hline $4(n=3)$ & $35-40$ & 37.50 & 7.50 & 2.74 \\
\hline Information derived from the study data. & & & &
\end{tabular}

$40 \%$ (mean 39.17, with an SD of 6.65). The sample corresponding to chain No. 4 had a range from $35 \%$ to $40 \%$ (mean 37.50 , with an SD of 2.74 ). The composition of the sample hamburgers from different establishments and related statistical analysis is shown in tables 1 and 2 and in figure 1.

Fifteen samples of chicken nuggets, three samples of nuggets from each chain, from four different fastfood companies, and homemade sample were examined in total.

The percentages of skeletal muscle tissue found in the analyzed nugget samples ranged from a minimum of $5 \%$ to a maximum rate of $70 \%$ (mean from 15.83 to 68.83 , with an SD of $3.76-8.80$ ), with the latter value corresponding to the nugget sample prepared at home. The homemade sample had a range from $65 \%$ to $70 \%$ (mean 65.83 , with an SD of 2.04). The sample corresponding to chain No. 2 had a range from $20 \%$ to $40 \%$ (mean 29.17 , with an SD of 7.36). The sample corresponding to chain No. 3 had a range from $15 \%$ to $35 \%$ (mean 22.50 , with an SD of 6.89). The sample corresponding to chain No. 4 had a range from $5 \%$ to $30 \%$ (mean 17.50 , with an SD of 8.80). The sample corresponding to chain No.
5 had a range from $15 \%$ to $35 \%$ (mean 24.17 , with an SD of 7.36).

We found no difference in the content of vegetable protein in 14 samples of nuggets and hamburgers. The amount of this kind of protein ranged from $0.5 \%$ to $1 \%$ in all the samples tested (Fig. 2).

The proportion of adipose tissue ranged between $10 \%$ and $70 \%$ (mean from 15.83 to 70 , with an SD of 3.76-10.49), with the lowest value corresponding to the homemade sample. The homemade sample had a range from $10 \%$ to $20 \%$ (mean 15.83 , with an SD of 3.76). The sample corresponding to chain No. 2 had a range from $50 \%$ to $65 \%$ (mean 56.67, with an SD of 6.06). The sample corresponding to chain No. 3 had a range from $15 \%$ to $35 \%$ (mean 22.50, with an SD of 6.89). The sample corresponding to chain No. 4 had a range from $55 \%$ to $75 \%$ (mean 70.00 , with an SD of 8.94). The sample corresponding to chain No. 5 had a range from $55 \%$ to $75 \%$ (mean 60, with an SD of 10.49).

The presence of bone and cartilage was detected in a range between $5 \%$ and a maximum of $15 \%$ in the analyzed nugget samples (mean from 0 to 0.83 , with an SD of 0-2.04). Abundant content of blood and blood vessels was found in all the samples. The 

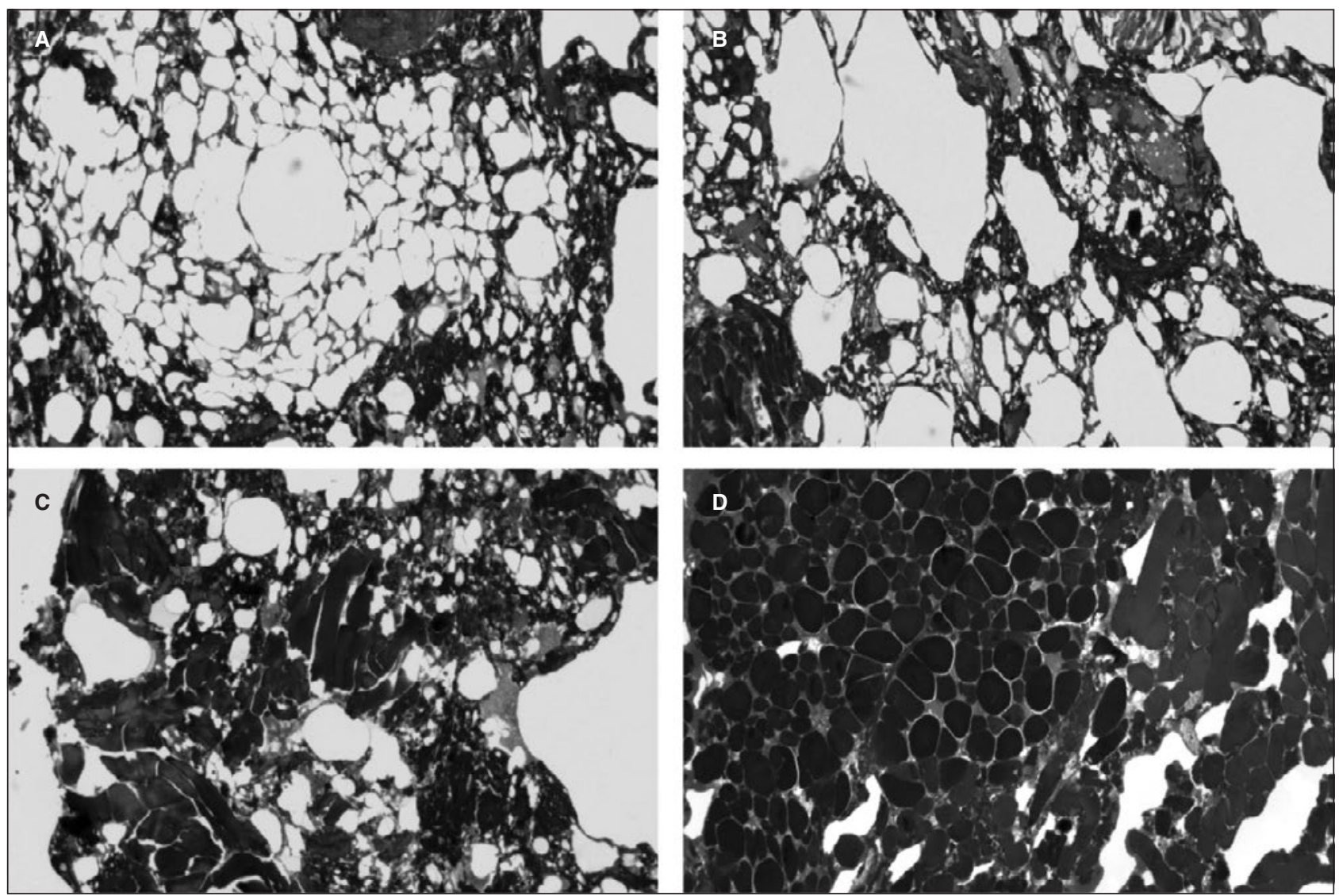

Figure 1. A: Microscopic view with Trichromic Masson and intermediate magnification ( $\times 10)$ of a sample consisting of $90 \%$ adipose tissue. B: Fragment of a sample formed of $75 \%$ adipose tissue. Red skeletal muscle fibers are present in the left inferior corner. T. Masson ( $\times 10)$. C: Microscopic view of a sample composed of adipose tissue and skeletal muscular in similar proportions. T. Masson (×10). D: Photomicrography showing a sample consisting predominantly of skeletal muscle T. Masson $(\times 10)$.

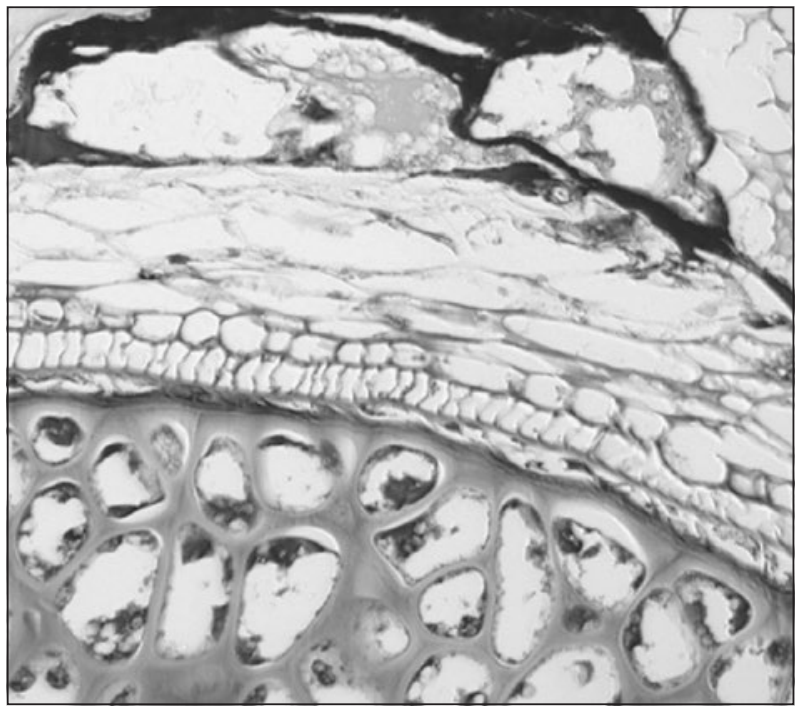

Figure 2. Photomicrograph showing a vegetable component that was identified with T. Masson technique in a nugget sample $(\times 40)$. composition of muscle and fat in the nugget samples from the various establishments is shown in tables 3 and 4.

\section{DISCUSSION}

The results obtained in our experimental study are similar to those reported by deShazo et al. ${ }^{1}$, who found that the protein content of chicken nuggets was minimal compared to the percentage of fat. They randomly selected nuggets from 1 day, from two different national fast-food chains, and fixed in formalin, sectioned, and stained for microscopic analysis. However, our group analyzed samples of nuggets from five different restaurant chains, to 
Table 3. Range of percentages and statistical analysis of muscle tissue content of chicken nugget samples from commercial establishments

\begin{tabular}{lcccc}
\hline $\begin{array}{l}\text { Food sample } \\
\text { ( } \text { of samples) }\end{array}$ & $\begin{array}{l}\text { Range of \% of } \\
\text { muscle tissue }\end{array}$ & Mean & Variance & Standard deviation \\
\hline Homemade $(n=3)$ & $60-70$ & 65.83 & 14.17 & 3.76 \\
\hline $2(n=3)$ & $20-40$ & 29.17 & 54.17 & 7.36 \\
\hline $3(n=3)$ & $15-35$ & 22.50 & 47.50 & 6.89 \\
\hline $4(n=3)$ & $5-30$ & 17.50 & 77.50 & 8.80 \\
\hline $5(n=3)$ & $15-35$ & 24.17 & 54.17 & 7.36 \\
\hline
\end{tabular}

Information derived from the study data.

Table 4. Range of percentages and statistical analysis of adipose tissue content of chicken nugget samples from commercial establishments

\begin{tabular}{lcccc}
\hline $\begin{array}{l}\text { Food sample } \\
\text { (n of samples) }\end{array}$ & $\begin{array}{l}\text { Range of \% of } \\
\text { adipose tissue }\end{array}$ & Mean & Variance & Standard deviation \\
\hline Homemade $(n=3)$ & $10-20$ & 15.83 & 14.17 & 3.76 \\
\hline $2(n=3)$ & $50-65$ & 56.67 & 36.67 & 6.06 \\
\hline $3(n=3)$ & $50-70$ & 57.50 & 97.50 & 9.87 \\
\hline $4(n=3)$ & $55-80$ & 70.00 & 80.00 & 8.94 \\
\hline $5(n=3)$ & $55-70$ & 60.00 & 110.00 & 10.49 \\
\hline
\end{tabular}

Information derived from the study data.

increase the validity of the study. These results are highly relevant for public health because according to the 2012 ENSANUT $^{8}$ (Encuesta Nacional de Salud y Nutrición, National Survey on Health and Nutrition) survey, Mexico ranks first globally in overweight and obesity, and the 2016 ENSANUT $^{9}$ survey showed an increase in obesity and overweight in adults older than 20 years. The high-fat content of both the analyzed chicken nuggets and hamburgers indicates that these foods should be avoided by adults and, especially, children.

A strength of our study compared with that carried out by deShazo et al. ${ }^{1}$ was the inclusion of a control sample for both the nuggets and hamburger patties, making it possible to compare the content of samples from commercial chains with a sample made from meat cooked at home. Both the control nuggets and burgers exhibited the highest percentages of protein, ranging from $60 \%$ to $75 \%$ (media 65 with an SD of 5.48) for the beef burger and $65 \%$ to $70 \%$ (media 65.83 with an SD of 3.76) for the nuggets.

Prayson et al. showed in their study that about half of the weight of the burgers was water and only a small percentage was meat. A variety of different tissues, such as bone, cartilage, and blood vessels, was also found in the analyzed hamburger meat ${ }^{2}$. Our research obtained similar results, with other components occurring in a range from $5 \%$ to $20 \%$ in the samples, and blood vessels and nerves were found in all samples.

As shown in table 1, results obtained from different samples of both nuggets and hamburgers show great variability of the same company on different days, of which the sample was taken in terms of percentage of protein, fat, and other content tissues (bone, cartilage, and blood vessels), which could imply a problem of quality control of the companies in its production process.

Unfortunately, in Mexico, the population has increased consumption of highly energetic food. Recently, a study concluded that $53 \%$ of kcal per capita in Mexico come from processed or packaged foods $/$ beverages ${ }^{10}$. It is recommended that health professionals (nutritionists, pediatricians, and physicians) provide appropriate education to their patients about the products sold in fast-food chains so 
that the patients can make informed choices among the various options and choose high-quality foods with good nutritional value.

As concluded in the research conducted by Denova-Gutiérrez et al., eating patterns have an influence on patients' cardiovascular risk, with high consumption of fruits, vegetables, and whole grains, leading to lower cardiovascular risk compared to subjects consuming large amounts of refined products, fats, simple sugars, and alcohol ${ }^{11}$. Recently, a study concluded that higher consumption of fast foods had undesirable effects on metabolic syndrome and was accompanied with a greater increase in serum triglyceride levels ${ }^{12}$. Medical professionals should inform patients about the limited nutritional value of many processed foods, including commercial chicken nuggets and hamburgers, and about the risks associated with high consumption of these products.

It is also necessary to carry out similar studies to analyze the nutritional content of fast foods in other Latin American countries to see if they corroborate the results of our research and previous studies ${ }^{1,2,7}$. If so, international strategies should be proposed to regulate the content of protein, fat, and other components in fast foods, with the aim of improving the nutritional quality of these products and reducing the high rates of overweight people and obesity (especially among children) around the world ${ }^{13}$.

Nutrition labeling is a tool that helps consumers assess food ingredients, energy content, and nutrient levels to choose more healthful options. It is important to regulate the labeling of the nutritional content of foods from fast-food chains as well as that of packaged, processed, and frozen products, which is covered by the Mexican Official Standard NOM-086-SSA1-199414,15. In Mexico, not all fastfood chains offer nutrition information for their products. The nutritional information is on their websites; however, some of the fast-food chains only provide this information on their American websites. Regulation of nutrition facts for the foods sold by fast-food chains should be promoted in Mexico. This would give consumers better knowledge of the nutritional value of various fast foods, allowing them to decide whether a menu item is appropriate for their diet, whether it is of high nutritional quality, and if it offers the needed nutrients for the development, growth, and performance of children and adolescents.

The dietary recommendations are based on "El Plato del buen Comer" (The Good Eating Plate) and on the Mexican equivalent system ${ }^{15}$. Sugars, fats, and fast-food products are not recommended foods in these dietary schemes. It is recommended that the Mexican population limits saturated fat to $<7 \%$ a day of polyunsaturated fat $6-10 \%$ of total energy from fat ${ }^{15}$. In addition, there is a limitation on the suggested maximum consumption of fast food per week. The high consumption of fast food in our country and the poor-quality control of their production necessitate the creation of dietary guidelines that regulate their consumption and that provide a maximum consumption recommendation for all ages. Hamburgers may be adulterated through the overuse of protein extenders. Among vegetables, soy protein is the best substitute for animal protein, these ingredients help to reduce the final product cost ${ }^{16,17}$. In some countries, such as in Brazil, only the maximum addition of $4.0 \%$ of "non-meat protein in aggregate form" is permitted ${ }^{15}$. In Mexico, norm NOM-122-SSA1-1994 lays down limits for additives, including for nonmeat protein and collagen for different meat products, and sanitary specifications. Limits for additives are as follows: soy protein isolate $(2.0 \%)$, soy concentrate (3.5\%), and collagen $(2.0 \%)^{18}$. These additives may be used provided that their total percentage does not exceed the maximum allowed for each one. There are methods for quantification of soy protein, such as the isotope method and multiplex polymerase chain reaction ${ }^{17,18}$. Our study methodology is limited by not using this technology, which limits the counting of the percentage of vegetable protein found in meat hamburgers and chicken nuggets.

This study is also limited using only one control sample for nuggets and hamburgers, which incurs a high risk of bias, as we cannot analyze for variation among the controls. Therefore, the comparison of the fast-food specimens to the controls is very weak evidence.

Our analysis concludes that the chicken nuggets and hamburgers sold by large fast-food chains in 
Mexico offer low levels of protein and a high content of fat and other components and, thus, contribute to obesity, diabetes, and their related systemic complications. National strategies and plans are needed to educate the population on the appropriate consumption of high fat, processed foods such as chicken nuggets and hamburgers, to improve the population's health and reduce the prevalence of chronic degenerative diseases related to obesity.

\section{FUNDING SOURCE}

None.

\section{REFERENCES}

1. deShazo RD, Bigler S, Skipworth LB. The autopsy of chicken nuggets reads "chicken little". Am J Med. 2013;126:1018-9.

2. Prayson B, McMahon JT, Prayson RA. Fast food hamburgers: what are we really eating? Ann Diagn Pathol. 2008;12:406-9.

3. Interim Summary of Conclusions and Dietary Recommendations on Total Fat and Fatty Acids From the Joint FAO/WHO Expert Consultation on Fats and Fatty Acids in Human Nutrition, 10-14 November. Geneva: World Health Organization; 2008. Available from: http://www.who.int/ nutrition/topics/FFA_summary_rec_conclusion.pdf. [Last accessed on 2015 Jun].

4. World Health Organization. Global Strategy on Diet, Physical Activity and Health, Resolution of the 57th World Health Assembly. Geneva: World Health Organization; 2004. Available from: http://www.who.int/ dietphysicalactivity/strategy/eb11344/strategy_english_web.pdf. [Last accessed on 2015 Jun].

5. The Lancet. Managing the tide of childhood obesity. Lancet. 2015;385:2434.

6. Duerksen SC, Elder JP, Arredondo EM, Ayala GX, Slymen DJ, Campbell $\mathrm{NR}$, et al. Family restaurant choices are associated with child and adult overweight status in Mexican-American families. J Am Diet Assoc. 2007; 107:849-53.

7. Prayson BE, McMahon JT, Prayson RA. Applying morphologic techniques to evaluate hotdogs: what is in the hotdogs we eat? Ann Diagn Pathol. 2008:12:98-102.

8. Gutiérrez J, Rivera-Dommarco J, Shamah-Levy T, Villalpando-Hernández S, Franco A, Cuevas-Nasu L. Encuesta Nacional de Salud y Nutrición 2012. Resultados Nacionales. Cuernavaca, México: Instituto Nacional de Salud Pública; 2012.

9. Shamah-Levy T, Ruiz-Matus C, Rivera-Dommarco J, Kuri-Morales P, Cuevas-Nasu L, Jiménez-Corona ME, et al. Encuesta Nacional de Salud y Nutrición de Medio Camino 2016. Resultados Nacionales. Cuernavaca, México: Instituto Nacional de Salud Pública; 2017. p. 98-105.

10. Popkin BM. Nutrition, agriculture and the global food system in low and middle income countries. Food Policy. 2014;47:91-6.

11. Denova-Gutiérrez E, Tucker KL, Flores M, Barquera S, Salmerón J. Dietary patterns are associated with predicted cardiovascular disease risk in an urban Mexican adult population. J Nutr. 2016;146:90-7.

12. Bahadoran Z, Mirmiran P, Hosseini-Esfahani F, Azizi F. Fast food consumption and the risk of metabolic syndrome after 3-years of follow-up: tehran lipid and glucose study. Eur J Clin Nutr. 2013;67:1303-9.

13. Cheung PC, Cunningham SA, Narayan KM, Kramer MR. Childhood obesity incidence in the united states: a systematic review. Child Obes. 2016;12:1-1.

14. Norma Oficial Mexicana NOM-086-SSA1-1994, Bienes y servicios. Alimentos y Bebidas no Alcohólicas con Modificaciones en su Composición. Especificaciones Nutrimentales. Available from: http://www.salud. gob.mx/unidades/cdi/nom/086ssa14.html. [Last accessed on 2015 Jun].

15. Bonvecchio-Arenas A, Fernández-Gaxiola AC, Plazas-Belausteguigoitia M, Kaufer-Horwitz M, Lizaur AB, Dommarco JA. Guías Alimentarias y de Actividad Física en Contexto de Sobrepeso y Obesidad en la Población Mexicana. Brazil: Academia Nacional de Medicina; 2015.

16. Ducatti $R$, de Almeida Nogueira Pinto JP, Sartori MMP, Ducatti C. Quantification of soy protein using the isotope method $(\delta(13) \mathrm{C}$ and $\delta(15) \mathrm{N})$ for commercial brands of beef hamburger. Meat Sci. 2016;122:97-100.

17. Tafvizi F, Hashemzadegan M. Specific identification of chicken and soybean fraud in premium burgers using multiplex-PCR method. J Food Sci Technol. 2016;53:816-23.

18. NORMA Oficial Mexicana NOM-122-SSA1-1994, Bienes y Servicios. Productos de la Carne. Productos Cárnicos Curados y Cocidos, y Curados Emulsionados y Cocidos. Especificaciones Sanitarias; 2016. Available from: http://www.salud.gob.mx/unidades/cdi/nom/122ssa14.html. (Last accessed 2016 Jun]. 